\title{
Genetic and epigenetic differences of benign and malignant pheochromocytomas and paragangliomas (PPGLs)
}

\author{
Fatemeh Khatami ${ }^{1}$, Mahsa Mohammadamoli ${ }^{2}$, Seyed Mohammad Tavangar ${ }^{1,3}$ \\ ${ }^{1}$ Chronic Diseases Research Center, Endocrinology and Metabolism Population Sciences Institute, Tehran University \\ of Medical Sciences, Tehran, Iran; ${ }^{2}$ Endocrinology and Metabolism Research Center, Endocrinology and Metabolism \\ Clinical Sciences Institute, Tehran University of Medical Sciences, Tehran, Iran; ${ }^{3}$ Department of Pathology, Dr. Shariati \\ Hospital, Tehran University of Medical Sciences, Tehran, Iran \\ E-mail:Tavangar@ams.ac.ir
}

\begin{abstract}
Pheochromocytomas and paragangliomas (PPGLs) are tumors arising from the adrenal medulla and sympathetic/parasympathetic paraganglia, respectively. According to The Cancer Genome Atlas (TCGA), approximately 40\% of PPGLs are due to germ line mutations in one of 16 susceptibility genes, and a further $30 \%$ are due to somatic alterations in at least seven main genes (VHL, EPAS1, CSDE1, MAX, HRAS, NF1, RET, and possibly KIF1B). The diagnosis of malignant PPGL was straight forward in most cases as it was defined as presence of PPGL in non-chromaffin tissues. Accordingly, there is an extreme need for new diagnostic marker(s) to identify tumors with malignant prospective. The aim of this study was to review all suggested genetic and epigenetic alterations that are remarkably different between benign and malignant PPGLs. It seems that more than two genetic mutation clusters in PPGLs and other genetic and methylation biomarkers could be targeted for malignancy discrimination in different studies.
\end{abstract}

Key words: pheochromocytoma, paraganglioma, genetic, epigenetic, methylation

Pheochromocytomas and paragangliomas (PPGLs) are rare neuroendocrine tumors which arise in the sympathetic and parasympathetic paraganglia (Boron and Boulpaep 2009). According to WHO definition "intra-adrenal paraganglioma, highlighting the common origin of phaeochromocytomas and sympathetic or parasympathetic paragangliomas, which are all derived from neuroectoderm and can all occur in patients with the same genetic predisposition" (DeLellis et al. 2004; Favier et al. 2015). The majority of PPGLs are sporadic and benign with incidence rate of about $0.4-9.5$ per $10^{6}$ people (Stenstrom and Svardsudd 1986; Larijani et al. 2004), produce catecholamine's, nor epinephrine and/or epinephrine as PPGL may produce a combination or be strictly noradrenergic (Eisenhofer et al. 2004a). According to grading system for adrenal phaeochromocytoma and paraganglioma (GAPP), the tumors are scored based on histological pattern, cellularity, comedotype necrosis, capsular/vascular invasion, Ki67 labeling index, and catecholamine type and are graded as one of the three types: well-differentiated (WD, 0-2 points), moderately differentiated (MD, 3-6 points) and poorly differentiated (PD, 7-10 points) (Kimura et al. 2014).The morbidity and mortality of these tumors are related to its aggressive behavior, metastasis, and effective role of catecholamine's on different organs like cardiovascular system (Capelli et al. 2009, Yalcin and Oberg 2015). The tumor is malignant in $10 \%$ of cases and unfortunately is not curable completely by surgical removal. Many tumors of PPGLs remain unrecognized and are diagnosed only during

Corresponding author: Seyed Mohammad Tavangar, Department of Pathology, Dr. Shariati Hospital, Tehran University of Medical Sciences, Tehran, Iran; phone: +98 21 84902187; fax: +98 21 88633078; e-mail address: Tavangar@ams.ac.ir. 
postmortem examination (McNeil et al. 2000). Measurements of plasma methoxytyramine, the O-methylated dopamine metabolite, are useful for detecting rare dopamine-producing PPGLs and head and neck paragangliomas (HNPGLs) (Rao et al. 2017). Unfortunately, it has not been a comprehensive approach in diagnosis and treatment of malignant PPGLs yet (Thompson 2002).

Because PPGLs have been demonstrated to exhibit intra- and inter-tumor heterogeneity in terms of biology, there is a real chance that location bias could be incorporated in most of the studies conducted so far. However, some histological features have been described as diagnostic or predicting tools in different tumors (Kleihues et al. 2002; Tavangar et al. 2004). In malignant PPGLs, some features including necrosis, vascular invasion, and extensive capsular invasion have been reported to correlate with malignancy (Linnoila et al. 1990; van der Harst et al. 2000). Prognostic value of PCCs of the Adrenal Gland Scaled Score (Pass score) tests to separate benign from malignant neoplasms has been introduced by Thompson et al. (2002). Several histological features have been taken into consideration including growth pattern, necrosis, local and metastatic invasion, nuclear pleomorphic, cellularity and cellular monotony, tumor cell spindling, mitotic count and atypical mitotic figures (Thompson 2002). Paying inadequate consideration to how blood is collected and how results are interpreted influences the high rates of misdiagnosis and major problem that comes from this inability to identify metastatic PPGL is that all cases with $\mathrm{R} 0$ resection needs long follow-up and (Yu et al. 2009; Chen et al. 2010; Guo and Lloyd 2015).

Thanks to recent advances in genetic science, some mutations with various consequences like protein expression, immune-reactivity alongside with epigenetic alterations, have been considered as appropriate discriminative markers for malignancy in different tumors (Tavangar et al. 2005; Haghpanah et al. 2006; Tavangar et al. 2007; Sarmadi et al. 2009; Tabriz et al. 2009; Mohammadi-asl et al. 2011; Sanii et al. 2012). It has been reported that up to $40 \%$ of patients with PPGLs have a germ line mutation in recognized susceptibility genes (Mannelli et al. 2009; Fishbein et al. 2013; Favier et al. 2015), the exact molecular differentiation between benign and malignant PPGLs is not understood at all. In this review, we provide an overview to the current data on genetic and epigenetic alterations of PPGLs as well as diversity of these variations between benign and malignant tumors.

\section{Genetic mutations clustering in PPGLs}

PPGLs have been suggested that are usually associated with 3 syndromes - Von Hippel-Lindau (VHL) syndrome (Hasani-Ranjbar et al. 2009), multiple endocrine neoplasia type 2 (MEN 2; Hasani-Ranjbar et al. 2011), and neurofibromatosis type 1 (NF1). Around $40 \%$ of PPGLs patients have a germ line mutation in one of the 16 famous susceptibility genes: RET, NF1, VHL, succinate dehydrogenases (SDHA, SDHB, SDHC, SDHD, and SDHAF2), TMEM127, PHD1, PHD2, HIF2A, FH, Myc-associated factor (MAX), and KIF1B (Bayley et al. 2010; Majidi et al. 2011; Burnichon et al. 2012; Darr et al. 2012; Galan and Kann 2013; Letouze et al. 2013; Castro-Vega et al. 2014; Dahia 2014; Welander et al. 2014; Yang et al. 2015). In fact, there are two separate gene clusters taking part in the tumor genesis of PPGLs according to their transcriptional profile; kinase receptorsignaling gene cluster (associated with RET/NF1/ TMEM127/MAX/ KIF1B mutations) and a pseudohypoxic gene cluster (associated with mutations in VHL/SDHx/PHD2 genes) (Nolting and Grossman 2012). According to the signaling pathways and transcriptome studies, all candidate genes for PPGLs are grouped in two clusters that seem to show separate and discrete routes for tumor genesis.

The first group (Group I), there are $V H L, S D H$, and prolyl hydroxylase domain $P H D$ genes as well as markers of pseudohypoxia (EPAS1, NOX4, LOXL2), angiogenesis factors like (vaso-endothelial growth factor, VEGF) (Gimenez-Roqueplo 2004), and reduced oxidative response (Baysal et al. 2002; Neumann et al. 2002; Bryant et al. 2003; Dahia et al. 2005; Nolting and Grossman 2012; Zhikrivetskaya et al. 2017). The second group (Group II) includes the RET, NF1, trans-membrane protein 127 (TMEM127), kinesin family member 1B-beta isoform $(K I F 1 B \beta)$, and $M A X$ genes (Zhikrivetskaya et al. 2017). Additionally, tumors of this group are considered to by the diminished regulation of several signaling pathways [PI3K/AKT, RAS/RAF/ERK, and mTORC1/p70S6 kinase $(p 70 S 6 K)]$ besides translation initiation, protein synthesis, and neuronal (SHANK2 and RET) plus neuroendocrine (PNMT, NCAM2, and CADPS) differentiation (Kajbafzadeh et al. 2006; Salajegheh et al. 2011; Nolting and Grossman 2012; Salajegheh et al. 2013; Zhikrivetskaya et al. 2017).

As it is shown in Figure 1, in the normal state group 1 gene contributes to the hypoxia response, so these gene mutations cause activation of effecter molecules in the absence of hypoxia. Group I tumors show a bigger rate of angiogenesis and over expres- 
sion of VEGF and its receptors (Favier and Gimenez-Roqueplo 2010, 2012).The second set (cluster II) comprises of the protooncogene RET (which encodes a receptor tyrosine kinase) or the tumor suppressor genes (NF1, TMEM127, MAX, or KIF1B $\beta$ ) and related kinase signaling pathways; for example, PI3Kinase/AKT and $m$ TOR (Figure 2) (Favier and Gimenez-Roqueplo 2010, 2012; Gimenez-Roqueplo et al. 2012; Zhikrivetskaya et al. 2017). The second set (cluster 2) comprises of the proto-oncogene $R E T$ (which encodes a receptor tyrosine kinase) or the tumor suppressor genes $N F 1$, TMEM127, MAX, or KIF1B $\beta$ and related kinase signaling pathways (Amar et al. 2005; Comino-Mendez et al. 2011; Shuch et al. 2014). This cluster, which is a kinase signaling cluster, involves genetic mutations associated with abnormal stimulation of kinase signaling pathways such as PI3Kinase/AKT, and the $m T O R$ pathway (Gimenez-Roqueplo et al. 2012). In Figure 2, the molecular pathway of these genes and downstream targets are shown.

These two clusters are additionally subdivided according to their transcription

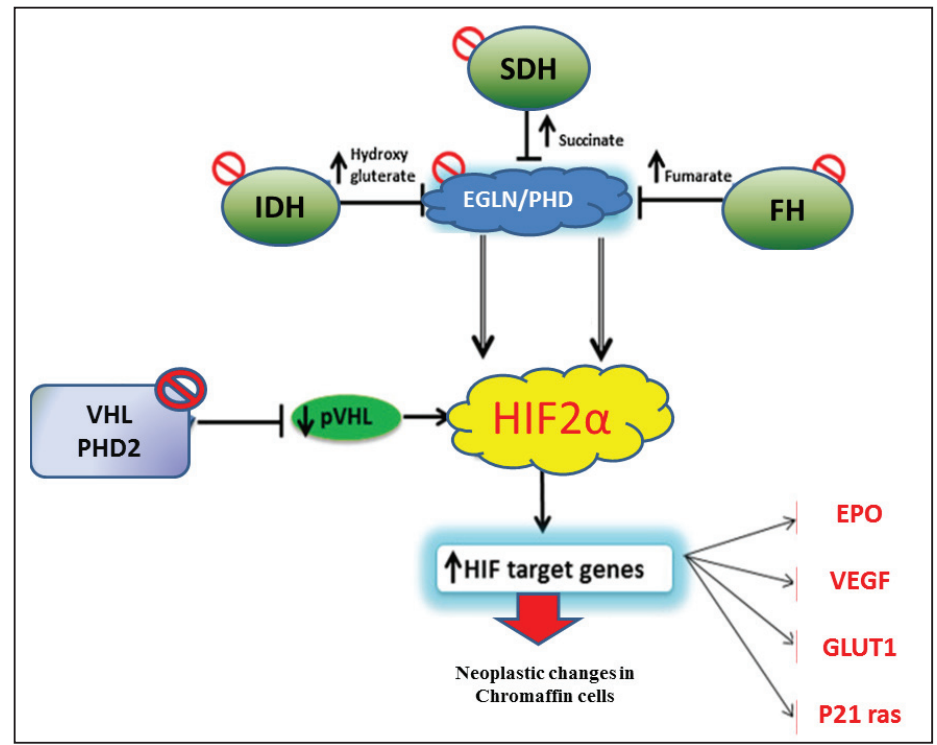

Figure 1. Impaired hypoxic status regulation owing to mutations in Group 1 genes (genes involved in the pseudohypoxic pathway of tumor development). Mutations in VHL, SDH, HIF2A, PHD2, and FH genes (pink color) may lead to activation of the transcription factor HIF-1 and its target genes that promote pseudo hypoxic oncogenes (Zhikrivetskaya et al. 2017). In the normal state, these genes participate in the response to hypoxia; conversely, mutations impair the regulation of this response, principal to the activation of effectors molecules in the absence of hypoxia. Group I tumors display an increased rate of angiogenesis and elevated expression of VEGF and its receptors. Remarkably, these elevated expression levels have been observed in both benign and malignant paragangliomas.

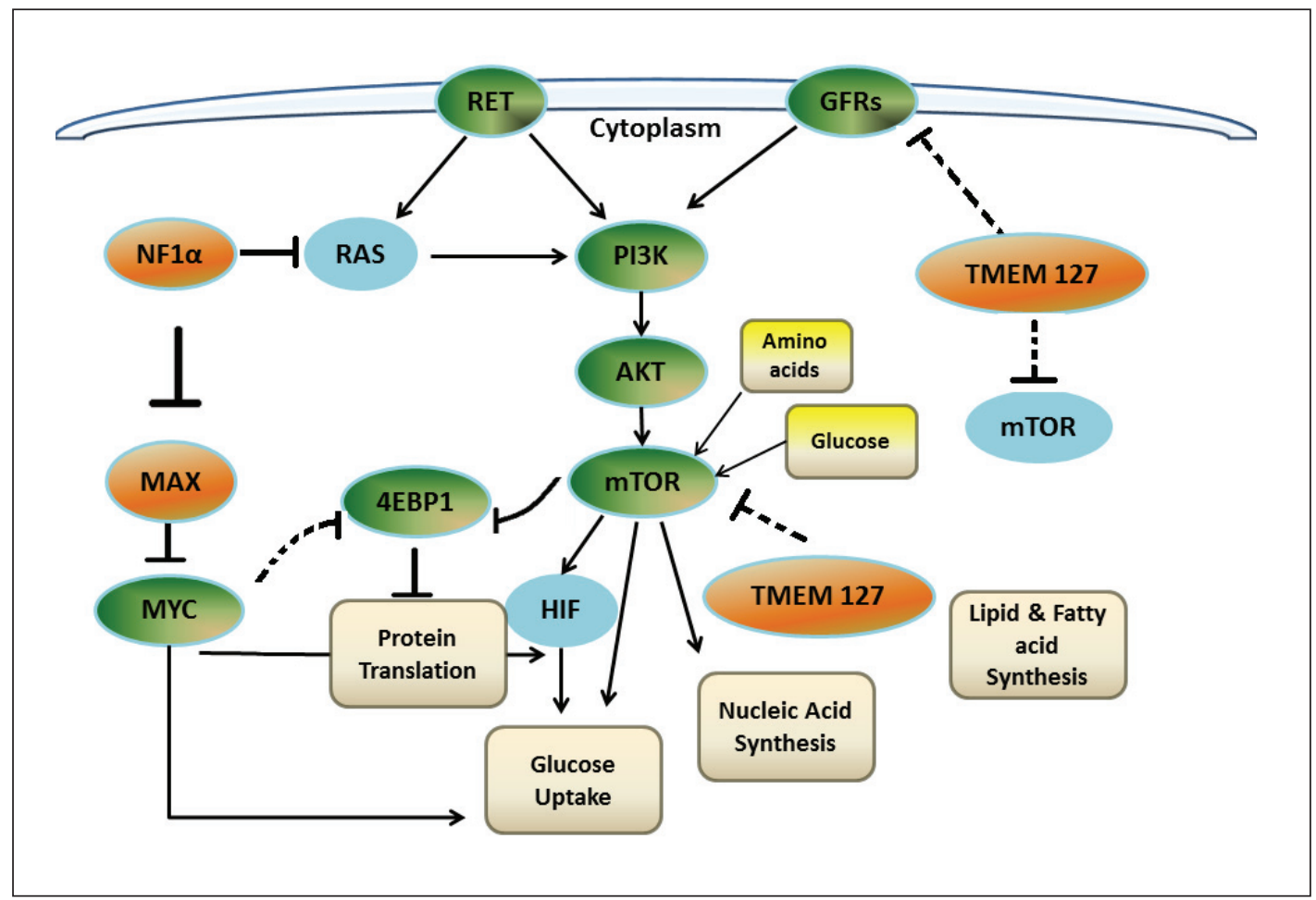

Figure 2. Impaired growth factor signaling owing to mutations in Group 2 genes (Zhikrivetskaya et al. 2017). 
profiles (Pillai et al. 2016) (Figure 3). Cluster 1 could be distributed into sub cluster $1 \mathrm{~A}$ and $1 \mathrm{~B}$, cluster 1 A contains PPGLS related to $S D H x$ and $F H$, while Cluster $1 \mathrm{~B}$ contains tumors with HIF2A and $V H L$, respectively (Lopez-Jimenez et al. 2010). Cluster 2 can be divided into groups $2 \mathrm{~A}, 2 \mathrm{~B}, 2 \mathrm{C}$, and $2 \mathrm{D}$. Group $2 \mathrm{~A}$ is consisting of RET, MAX, NF1 and TMEM127 mutated tumors but groups $2 \mathrm{~B}$ and $2 \mathrm{C}$ are sporadic tumors (Dahia et al. 2005). Group 2D tumors carry unknown mutations related to PPGLs (Figure 3).

The genes VHL, SDHX from Group I and RET, and NF1 from Group II are highly required for apoptosis in neuronal precursor cells. The c-Jun protein is activated in the absence of signal from nerve growth factor (NGF) and causes neuronal cell apoptosis (Palmada et al. 2002). In the absence of neurofibromin the NF1 gene product prevents the NGF receptor TrkA and the embryonic sympathetic neurons survive even without the NGF signal (Vogel et al. 1995; Palmada et al. 2002). It has been shown that in the pheochromocytoma-derived cell line PC12, the succinate increase made cell growth through inhibiting PHD3-dependent apoptosis, which directed to the embryonic neurons survival and the PPGLs development (Lee et al. 2005). VHL protein inactivation leads to Jun-B mutation (an antagonist of c-Jun) (Lee et al. 2005). The Prolyl hydroxylase 3 (PHD3) protein is necessary and sufficient for apoptosis induction after the termination of the NGF signal; consequently, damaging this protein function or impairment of its regulation through succinate accumulation, inhibits apoptosis and resulting in tumor formation (Lee et al. 2005; Zhikrivetskaya et al. 2017). Moreover, the contribution of menin protein, which is coded by multiple endocrine neoplasia type 1 (MEN1) in c-Jun activation and its suppression by the MYC protein propose that mutations in MEN1 and MAX can play a crucial role in PPGLs development (Agarwal et al. 1999; Vaque et al. 2008; Akerstrom 2016). Interestingly, a blood-based MAAA (NETest) has newly been industrialized for neuroendocrine tumors (NETs) (Li et al. 2013; Walenkamp et al. 2014; Kidd et al. 2015; Peczkowska et al. 2017) and confirmed to have efficacy in identifying residual disease (Modlin et al. 2016), describing progression (Pavel et al. 2017) and predicting treatment efficacy (Cwikla et al. 2015).

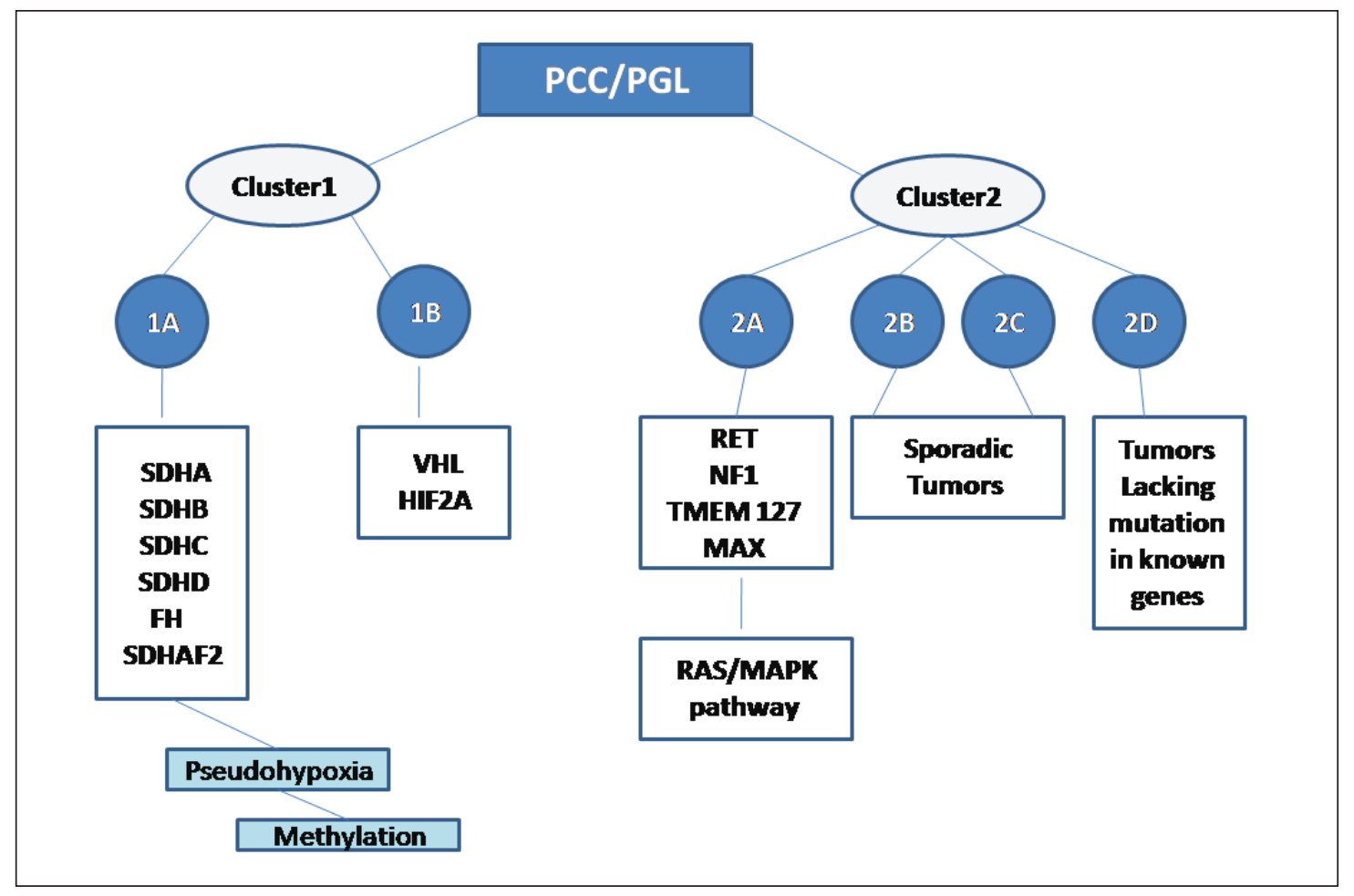

Figure 3. The subdivisions of cluster 1 and 2 genes in PPGLs accordingly to tumor biology. Cluster 1 genes could be divided into 2 groups. Cluster $1 \mathrm{~A}$ contains $S D H x$ and $F H$, while Cluster $1 \mathrm{~B}$ contains tumors with $H I F 2 A$ and $V H L$, respectively. Cluster 2 can be divided into subcluster 2A, 2B, 2C and 2D. Subcluster 2A comprises RET, MAX, NF1 and TMEM127 mutated tumors, whereas subcluster $2 \mathrm{~B}$ and $2 \mathrm{C}$ are sporadic tumors. Cluster $2 \mathrm{D}$ are tumors lacking known mutations related to PPGLs (Pillai et al. 2016). 


\section{Genetic differences between benign and malignant PPGLs}

Diagnosis of malignant "PPGLs", which presents about $10-15 \%$ of cases, is still under debate. Histological perception from benign cases is untrustworthy, so there is no definite diagnosis or cure for metastatic courses (Eisenhofer et al. 2004b). The exact molecular distinction of benign and malignant PPGLs could be a valuable development. In this respect, some tissue specific indicators for malignancy have been characterized, including different angiogenetic factors (Favier et al. 2002; Salmenkivi et al. 2003), cyclooxygenase-2 (Salmenkivi et al. 2001), secretogranin II-derived peptide (Yon et al. 2003). The $90 \mathrm{kDa}$ heat shock protein (Hsp90) as a key for telomerase activation and malignant transition in PPGLs have been described as a possible therapeutic target in advanced PPGLs (Giubellino et al. 2013). Moreover, overexpression of human telomerase reverse transcriptase ( $h T E R T)$ and related high telomerase activity (Boltze et al. 2003) or high Ki-67/MIB-1 immuno-reactivity (Elder et al. 2003; Tavangar et al. 2010) could be the indicator of the invasive behavior of tumor with remarkable specificity (Elder et al. 2003). Tumor size and the histomorphologic patterns (spindle cell and small round cell) have been expressively related to the tumor behavior, Ki-67 positivity and c-erbB-2 expression were suggested as immunohistochemical markers for predicting the malignant behavior of PPGLs (Nasseri-Moghaddam et al. 2003; Tavangar et al. 2010).Transformed $h s p 90$ and hTERT not only are valuable for the classification of PPGLs as malignant, but could also be beneficial for choosing the best therapeutic policy, because cancer cells are mainly dependent on hsp90 to guarantee precise folding and function of mutated and overexpressed oncoproteins. In fact telomerase catalytic subunit ( $h T E R T$ ) activity and Hsp90 expression possibly will act as molecular markers for early diagnosis of malignancy, so before the surgery of familial syndromes which are considered both in benign and malignant PPGLs, testing HSP90 and hTERT is highly demanded (Salmenkivi et al. 2004; Scholz et al. 2007). Contradictory, it has been shown that SDHB status and primary tumor size were more predictive of patient outcome than Ki-67 (Assadipour et al. 2017). SDHB mutations in patients with malignant PPGLs were linked to the shorter survival so it has prognostic value for malignancy specially for patients with an apparent sporadic and/or benign presentation at diagnosis (Amar et al. 2007). Germ line SDHB mutations have also been associated with renal cell carcinoma, gastrointesti- nal stromal tumors, and papillary thyroid carcinoma (Mulukutla et al. 2016).

The GATA3 belongs to the GATA family of transcription factors that regulate luminal epithelial cell differentiation in the mammary gland and plays fundamental roles in cell-fate specification (KourosMehr et al. 2006). The staining pattern of GATA3 showed that as a part of a panel of immunohistochemical markers, GATA3 was beneficial for differential diagnosis (Perrino et al. 2017). Moreover, down-regulation of six metastasis suppressor genes in malignant PPGLs had been shown using quantitative real-time polymerase chain reaction (qRT-PCR) (Ohta et al. 2005). These metastasis suppressor genes are $n m$ 23-H1, TIMP-4, BRMS-1, TXNIP, CRSP-3 and $E$-Cad that were down-regulated considerably in malignant PPGLs (Ohta et al. 2005; Saffar et al. 2011). Negative $n m-23$, laterally with positive $C O X-2$ or $g a$ lectin-3 indicated presence of malignancy and dual negativity for galectin-3 and COX-2, alongside with positive nm-23 specified benign behavior (Saffar et al. 2011). Erythroblast leukemia viral oncogene homolog $2(E R B B-2)$ encodes a member of the epidermal growth factor $(E G F)$ receptor family of receptor tyrosine kinases. The over expression of $E R B B-2$, as an early event of tumor genesis, was more observed in malignant than benign PPGLs by multiplex ligationdependent probe amplification and immunohistochemistry (Yuan et al. 2008). The microarray analysis of differentially expressed genes uncovered the lower expression of three key genes encoding peptide processing and activation factors including peptidyl glycine $\alpha$ amidating monooxygenase (PAM), glutaminylpeptide cyclotransferase (QPCT) and neuropeptide $\mathrm{Y}(N P Y)$ in malignant PPGLs (Helman et al. 1989; Thouennon et al. 2007). An assessment of the data of PPGLs from 90 patients, including 20 with malignant tumors identified, a total of 636 genes that discriminated benign from malignant disease at a significance level (Brouwers et al. 2006).The expression of $70 \%$ of these genes were reduced in malignant compared to benign tumors (Brouwers et al. 2006), proposing that malignant potential is largely characterized by a lessdifferentiated pattern of gene expression (Brouwers et al. 2006). Fishbein et al. $(2016,2017)$ described a comprehensive molecular characterization of PPGLs which are driven by diverse alterations affecting multiple genes and pathways. According to The Cancer Genome Atlas (TCGA), Cold Shock Domain-containing E1 gene (CSDE1) mutations resulted in decreased expression and may lead to inhibition of apoptosis, or programmed cell death. By diminishing apoptosis, CSDE1 mutations may prevent the cell's normal 
process of self-destruction (Fishbein et al. 2017). In fact, CSDE1 was a somatically mutated driver gene, accompanying four known drivers (HRAS, RET, EPAS1, and NF1). Furthermore, fusion genes in PPGLs, involving Mastermind like Transcriptional Coactivator 3 (MAML3), BRAF, NGFR, and NF1 were explored (Fishbein et al. 2017) but no dissimilarities between malignant and benign have been described. Unique MAML3 fusion genes spanned three isoforms and were triggering based on overexpression of MAML3 and on fusion transcript exonic expression (Fishbein 2016). The association between MAML3 overexpression and activation of the Wht signaling pathway has been shown resulting to bigger cell proliferation and metastasis (Fishbein 2016). Suggesting three molecular markers were positively linked with clinically aggressive disease: germline mutations in $S D H B$, somatic mutations in $A T R X$, a $S W I / S N F$ chromatin remodeling protein (Fishbein et al. 2015), and fusions involving MAML3 (Fishbein 2016).

Circulating tumor DNA and cells are one of the newest topics in cancer diagnosis policies (Khatami et al. 2017a,b). To assess whether a 51-neuroendocrine gene in blood analysis has clinical value as a diagnostic and prognostic marker circulating neuroendocrine tumor mRNA measured had been checked by qPCR analysis and positive circulating NET transcript analysis in well-differentiated PPGLs was shown (Peczkowska et al. 2017). Cell cycle arrest/ release proteins, like P53, Bcl-2, $m d m-2$, cyclinD1, $p 21$, and $p 27$, appear to have no role in foretelling the behavior of PPGLs contrary to Ki-67 which is really beneficial risk for recurrence risk assessment (Strong et al. 2008). The expression of pituitary tumor transforming gene (PTTG1), an anaphase-promoting complex $(A P C)$ substrate, suggested as a potential marker for distinguishing benign versus malignant tumors (Amousha et al. 2015). A pair-wise (tumor-normal) whole-exome sequencing to analyze the somatic mutational landscape of malignant PPGLs pointed out mutations in transport and cell adhesion genes, like $\mathrm{N}$-myc proto-oncogene protein $(M Y C N)$, myosin VB (MYO5B) and vinculin (VCL) (Wilzen et al. 2016). It was established that $M Y O 5 B$ mutation is indicator of malignancy, so deregulation of $R a b$ and Rac/Rho pathways could play significant role in PPGLs tumor genesis (Wilzen et al. 2016). Lysine methyltransferase 2D (KMT2D) is a histone methylatransferase and a component of a large protein complex called ASCOM (transcriptional regulator of the beta-globin and estrogen receptor genes). It has been indicated that $K M$ T2D expression was up regulated in PCCs compared to normal adrenals and its over expression certainly boosted cell migration in a PCC cell line (Juhlin et al. 2015). More than that a study disclosed a new function for $\mathrm{FH}$ in susceptibility to malignant and/or multiple PPGLs. Surprisingly, FH-deficient PPGLSs show the same pattern of epigenetic deregulation as SDHB-mutated malignant PPGLs. Then, they suggested that FH mutation screening could be included in PPGLS genetic testing, especially for tumors with malignant behavior (Castro-Vega et al. 2014). PPGLSs with somatic ATRX mutations are coupled with alternative lengthening of telomeres and clinically aggressive behavior because loss of ATRX, a SWI/SNF chromatin remodeling protein, is extremely essential in the development of clinically aggressive PPGLs (Fishbein et al. 2015). In Table 1, genetic alteration and resulting protein product changes, which were evidence for meaningful differences in malignant PPGLs are summarized.

\section{Epigenetic differences between benign and malignant pheochromocytoma}

Epigenetic changes are essential in molecular oncology because they affect gene transcription without changing the sequence of DNA. Aberrant DNA methylation has been known as one of the main features of human cancers (Jones 1986; Khatami et al. 2009a,b). Early studies were based on sequencing and PCR based methods to investigate the methylation status of carefully selected candidate genes (Geli et al. 2007; Muscarella et al. 2008), whereas latest studies have used array based on technologies to explore genome wide methylation (Letouze et al. 2013; de Cubas et al. 2015; Backman et al. 2017). The methylation level of some $\mathrm{CpG}$-sites was projected as indicator of malignancy in PPGLs (de Cubas et al. 2015). Epigenetic profiling of PPGLs has been done to evaluate promoter CpG-methylation of some candidate genes (Geli et al. 2007; Margetts et al. 2008). Differentially methylated genes of normal tissue, benign tumors, and malignant tumors suggested that abnormal DNA methylation influence genes involved in cell cycle regulation and tumor morphology (Backman et al. 2015). The integrated analysis of the tumor expression made clear that there is a definite association between histone methylations and DNA copy number alterations on global gene transcription (Sandgren et al. 2010). Global DNA methylation analysis acknowledged two distinct clusters of tumors characterized by different methylation patterns and different driver mutations (Backman et al. 2017).

Remarkably, several candidate tumor suppressor genes are recognized with decreased expression like 
TGIF1, DSC3, TNFRSF10B, RASSF2, HOXA9, PTPRE and $C D H 11$ and some other genes with increased expression including GNAS, INSM1, DOK5, ETV1, RET, NTRK1, IGF2 (Sandgren et al. 2010). Also, according to the different methylation patterns two distinct clusters of tumors are categorized as driver mutations (Backman et al. 2017). Among 12 candidate CpG sites, one hypermethylated site (cg02119938) and one hypomethylated site (cg26870725) were suggested as important sites in PPGLs (Oishi et al. 2016). These

Table 1

The list of different molecules that had been shown as an indicator of malignancy in pheochromocytomas and paragangliomas.

\begin{tabular}{|c|c|c|c|}
\hline Target Molecule & Detected Alteration & Detection Method & References \\
\hline Cyclooxygenase- 2 & Overexpression & $\begin{array}{l}\text { Immunohistochemistry } \\
\text { Northern blot } \\
\text { Western blot analyses }\end{array}$ & Salmenkivi et al. 2001 \\
\hline $\begin{array}{l}\text { secretogranin II-derived } \\
\text { peptide EM66 }\end{array}$ & Immunoreactivity & Immunohistochemistry & Yon et al. 2003 \\
\hline hsp90 & Overexpression & RT-PCR & $\begin{array}{l}\text { Boltze et al. 2003; } \\
\text { Giubellino et al. } 2013\end{array}$ \\
\hline hTERT & $\begin{array}{l}\text { Overexpression and } \\
\text { Telomerase Activity }\end{array}$ & $\begin{array}{l}\text { RT-PCR } \\
\text { TRAP assay }\end{array}$ & $\begin{array}{l}\text { Boltze et al. 2003; } \\
\text { Salmenkivi et al. 2004; } \\
\text { Scholz et al. } 2007\end{array}$ \\
\hline$n m 23-H 1$ & Down-regulation & qRT-PCR & $\begin{array}{l}\text { Ohta et al. 2005; } \\
\text { Saffar et al. } 2011\end{array}$ \\
\hline TIMP-4 & Down-regulation & qRT-PCR & Ohta et al. 2005 \\
\hline BRMS-1 & Down-regulation & qRT-PCR & Ohta et al. 2005 \\
\hline TXNIP & Down-regulation & qRT-PCR & Ohta et al. 2005 \\
\hline CRSP-3 & Down-regulation & qRT-PCR & Ohta et al. 2005 \\
\hline E-Cadherin & Down-regulation & qRT-PCR & Ohta et al. 2005 \\
\hline$E R B B-2$ & Overexpression & $\begin{array}{l}\text { Multiplex ligation-dependent } \\
\text { probe amplification and } \\
\text { immunohistochemistry }\end{array}$ & Yuan et al. 2008 \\
\hline c-erbB-2 & Overexpression & Immunohistochemistry & Tavangar et al. 2010 \\
\hline Ki-67/MIB-1 & Immunoreactivity & Immunohistochemical staining & $\begin{array}{l}\text { Elder et al. 2003; } \\
\text { Assadipour et al. 2017; } \\
\text { Tavangar et al. } 2010\end{array}$ \\
\hline PAM & Overexpression & Microarray analysis & $\begin{array}{l}\text { Thouennon et al. } 2007 \text {; } \\
\text { Helman et al. } 1989\end{array}$ \\
\hline QPCT & Overexpression & Microarray analysis & $\begin{array}{l}\text { Thouennon et al. 2007; } \\
\text { Helman et al. } 1989\end{array}$ \\
\hline NPY & Overexpression & Microarray analysis & $\begin{array}{l}\text { Thouennon et al. } 2007 \text {; } \\
\text { Helman et al. } 1989\end{array}$ \\
\hline$S D H B$ & Mutation & & Amar et al. 2007 \\
\hline GATA3 & Expression & Immunohistochemistry & $\begin{array}{l}\text { Kouros-Mehr et al. 2006; } \\
\text { Perrino et al. } 2017\end{array}$ \\
\hline PTTG1 & Expression & Immunohistochemistry & Amousha et al. 2015 \\
\hline MYCN & Mutation & Whole-exome sequencing & Wilzen et al. 2016 \\
\hline MYO5B & Mutation & Whole-exome sequencing & Wilzen et al. 2016 \\
\hline$V C L$ & Mutation & Whole-exome sequencing & Wilzen et al. 2016 \\
\hline KMT2D & Overexpression & Whole-exome sequencing & Juhlin et al. 2015 \\
\hline galectin-3 & Overexpression & Immunoreactivity & Saffar et al. 2011 \\
\hline $\mathrm{FH}$ & Mutation & & Castro-Vega et al. 2014 \\
\hline ATRX & Mutation & Whole-exome sequencing & Fishbein et al. 2015 \\
\hline
\end{tabular}

Abbreviations: RT-PCR - reverse transcriptase polymerase chain reaction analysis; qRT-PCR - quantitative real-time polymerase chain reaction; TRAP - telomeric repeat amplification protocol 
sites were linked to ACSBG1 (acyl-CoA synthetase bubble gum family member 1) and MAST1 (microtubule-associated serine-threonine kinase 1), and there is a big possibility that epigenetic modifications in the malignant transformation of PPGLs is associated with ACSBG1 silencing or MASTloverexpression (Oishi et al. 2016).

In the near future, a comprehensive molecular testing of PPGLs possibly will be used to decide therapeutic approaches and assess diagnosis and prognosis biomarkers. Considering the current development of next-generation sequencing-based genetic screening and liquid biopsy, this technology appears to be as a good option to improve personalized managements of both PPGLs molecular diagnosis and patient management (Burnichon et al. 2016; Khatami and Tavangar 2017).

\section{Conclusions}

In summary, genetic and epigenetic alterations that are differentially expressed in benign against malignant PPGLs were identified and reported. Some of them are a member of clustering genes like $S D H B$, while some others are different. Moreover, the reports indicate identification of approximately 25 differentially expressed genes and variations in methylated genes in malignant and benign tumors.

\section{Acknowledgments}

Special thanks to Endocrinology and Metabolism Research Center, Endocrinology and Metabolism Clinical Sciences Institute, Tehran University of Medical Sciences, Tehran, Iran.

\section{References}

Agarwal SK, Guru SC, Heppner C, Erdos MR, Collins RM, Park SY, Saggar S, Chandrasekharappa SC, Collins FS, Spiegel AM, Marx SJ, Burns AL. Menin interacts with the AP1 transcription factor JunD and represses JunD-activated transcription. Cell 96, 143-152, 1999.

Akerstrom G. Introduction to symposium: 'New genetics with impact on treatment of endocrine tumour disease'. J Intern Med 280, 536-539, 2016.

Amar L, Bertherat J, Baudin E, Ajzenberg C, Bressac-de Paillerets B, Chabre O, Chamontin B, Delemer B, Giraud S, Murat A, Niccoli-Sire P, Richard S, Rohmer V, Sadoul JL, Strompf L, Schlumberger M, Bertagna X, Plouin PF, Jeunemaitre X, Gimenez-Roqueplo AP. Genetic testing in pheochromocytoma or functional paraganglioma. J Clin Oncol 23, 8812-8818, 2005.

Amar L, Baudin E, Burnichon N, Peyrard S, Silvera S, Bertherat J, Bertagna X, Schlumberger M, Jeunemaitre X, Gimenez-Roqueplo AP, Plouin PF. Succinate dehydrogenase B gene mutations predict survival in patients with malignant pheochromocytomas or paragangliomas. J Clin Endocrinol Metab 92, 3822-3828, 2007.

Amousha MRH, Sabetkish N, Heshmat R, Rajabiani A, Saffar H, Haghpanah V, Tavangar SM. Expression of the pituitary tumor transforming gene (PTTG1) in pheochromocytoma as a potential marker for distinguishing benign versus malignant tumors. Acta Med Iran 53, 236-241, 2015.

Assadipour Y, Sadowski SM, Alimchandani M, Quezado M, Steinberg SM, Nilubol N, Patel D, Prodanov T, Pacak K, Kebebew E. SDHB mutation status and tumor size but not tumor grade are important predictors of clinical outcome in pheochromocytoma and abdominal paraganglioma. Surgery 161, 230-239, 2017.

Backman S, Crona J, Maharjan R, Stalberg P, Hellman P, Bjorklund P. Global promoter methylation analysis identifies malignant pheochromocytomas. Meeting Abstracts, Adrenal Tumors, Glucocorticoid Regulation and Action, Endocrine Society's 97th Annual Meeting and Expo, FRI-358, 2015.

Backman S, Maharjan R, Falk-Delgado A, Crona J, Cupisti K, Stalberg P, Hellman P, Bjorklund P. Global DNA Methylation Analysis Identifies Two Discrete clusters of Pheochromocytoma with Distinct Genomic and Genetic Alterations. Sci Rep 7, 44943, 2017.

Bayley JP, Kunst HP, Cascon A, Sampietro ML, Gaal J, Korpershoek E, Hinojar-Gutierrez A, Timmers HJ, Hoefsloot LH, Hermsen MA, Suárez C, Hussain AK, Vriends AH, Hes FJ, Jansen JC, Tops CM, Corssmit EP, de Knijff P, Lenders JW, Cremers CW, Devilee P, Dinjens WN, de Krijger RR, Robledo M. SDHAF2 mutations in familial and sporadic paraganglioma and phaeochromocytoma. Lancet Oncol 11, 366-372, 2010.

Baysal BE, Willett-Brozick JE, Lawrence EC, Drovdlic CM, Savul SA, McLeod DR, Yee HA, Brackmann DE, Slattery WH 3rd, Myers EN, Ferrell RE, Rubinstein WS. Prevalence of SDHB, SDHC, and SDHD germline mutations in clinic patients with head and neck paragangliomas. J Med Genet 39, 178-183, 2002.

Boltze C, Mundschenk J, Unger N, Schneider-Stock R, Peters B, Mawrin C, Hoang-Vu C, Roessner A, Lehnert H. Expression profile of the telomeric complex discriminates between benign and malignant pheochromocytoma. J Clin Endocrinol Metab 88, 4280-4286, 2003. 
Boron WF, Boulpaep EL. (Eds.) Medical Physiology: A Cellular and Molecular Approach. Saunders, 2009.

Brouwers FM, Elkahloun AG, Munson PJ, Eisenhofer G, Barb J, Linehan WM, Lenders JW, De Krijger R, Mannelli M, Udelsman R, Ocal IT, Shulkin BL, Bornstein SR, Breza J, Ksinantova L, Pacak K. Gene expression profiling of benign and malignant pheochromocytoma. Ann N Y Acad Sci 1073, 541-556, 2006.

Bryant J, Farmer J, Kessler LJ, Townsend RR, Nathanson KL. Pheochromocytoma: the expanding genetic differential diagnosis. J Natl Cancer Inst 95, 1196-1204, 2003.

Burnichon N, Cascon A, Schiavi F, Morales NP, Comino-Mendez I, Abermil N et al. MAX mutations cause hereditary and sporadic pheochromocytoma and paraganglioma. Clin Cancer Res 18, 2828-2837, 2012.

Burnichon N, Buffet A, Gimenez-Roqueplo AP. Pheochromocytoma and paraganglioma: molecular testing and personalized medicine. Curr Opin Oncol 28, 5-10, 2016.

Capelli P, Martignoni G, Pedica F, Falconi M, Antonello D, Malpeli G, Scarpa A. Endocrine neoplasms of the pancreas: pathologic and genetic features. Arch Pathol Lab Med 133, 350-364, 2009.

Castro-Vega LJ, Buffet A, De Cubas AA, Cascon A, Menara M, Khalifa E, Amar L, Azriel S, Bourdeau I, Chabre O, Curras-Freixes M, Franco-Vidal V, Guillaud-Bataille M, Simian C, Morin A, Leton R, Gomez-Grana A, Pollard PJ, Rustin P, Robledo M, Favier J, Gimenez-Roqueplo AP. Germline mutations in FH confer predisposition to malignant pheochromocytomas and paragangliomas. Hum Mol Genet 23, 2440-2446, 2014.

Chen H, Sippel RS, O’Dorisio MS, Vinik AI, Lloyd RV, Pacak K; North American Neuroendocrine Tumor Society (NANETS). The North American Neuroendocrine Tumor Society consensus guideline for the diagnosis and management of neuroendocrine tumors: pheochromocytoma, paraganglioma, and medullary thyroid cancer. Pancreas 39, 775-783, 2010.

Comino-Mendez I, Gracia-Aznarez FJ, Schiavi F, Landa I, Leandro-Garcia LJ, Leton R, Honrado E, Ramos-Medina R, Caronia D, Pita G, Gomez-Grana A, de Cubas AA, Inglada-Perez L, Maliszewska A, Taschin E, Bobisse S, Pica G, Loli P, Hernandez-Lavado R, Diaz JA, Gomez-Morales M, Gonzalez-Neira A, Roncador G, Rodriguez-Antona C, Benitez J, Mannelli M, Opocher G, Robledo M, Cascon A. Exome sequencing identifies MAX mutations as a cause of hereditary pheochromocytoma. Nat Genet 43, 663-667, 2011.

Cwikla JB, Bodei L, Kolasinska-Cwikla A, Sankowski A, Modlin IM, Kidd M. Circulating transcript analysis (NETest) in GEP-NETs treated with somatostatin analogs defines therapy. J Clin Endocrinol Metab 100, E1437E1445, 2015.

Dahia PL, Ross KN, Wright ME, Hayashida CY, Santagata S, Barontini M, Kung AL, Sanso G, Powers JF, Tischler AS, Hodin R, Heitritter S, Moore F, Dluhy R, Sosa JA, Ocal IT, Benn DE, Marsh DJ, Robinson BG, Schneider K, Garber J, Arum SM, Korbonits M, Grossman A, Pigny P, Toledo SP, Nose V, Li C, Stiles CD. A HIF1alpha regulatory loop links hypoxia and mitochondrial signals in pheochromocytomas. PLoS Genet 1, 72-80, 2005.

Dahia PL. Pheochromocytoma and paraganglioma pathogenesis: learning from genetic heterogeneity. Nat Rev Cancer 14, 108-119, 2014.

Darr R, Lenders JW, Hofbauer LC, Naumann B, Bornstein SR, Eisenhofer G. Pheochromocytoma - update on disease management. Ther Adv Endocrinol Metab 3, 11-26, 2012.

de Cubas AA, Korpershoek E, Inglada-Perez L, Letouze E, Curras-Freixes M, Fernandez AF, Comino-Mendez I, Schiavi F, Mancikova V, Eisenhofer G, Mannelli M, Opocher G, Timmers H, Beuschlein F, de Krijger R, Cascon A, Rodriguez-Antona C, Fraga MF, Favier J, Gimenez-Roqueplo AP, Robledo M. DNA methylation profiling in pheochromocytoma and paraganglioma reveals diagnostic and prognostic markers. Clin Cancer Res 21, 3020-3030, 2015.

DeLellis RA, Lloyd RV, Heitz PU, Eng C. (Eds.): World Health Organization Classification of Tumours. Pathology and Genetics of Tumours of Endocrine Organs. IARC Press: Lyon 2004.

Eisenhofer G, Kopin IJ, Goldstein DS. Catecholamine metabolism: a contemporary view with implications for physiology and medicine. Pharmacol Rev 56, 331-349, 2004a.

Eisenhofer G, Bornstein SR, Brouwers FM, Cheung NK, Dahia PL, de Krijger RR, Giordano TJ, Greene LA, Goldstein DS, Lehnert H, Manger WM, Maris JM, Neumann HP, Pacak K, Shulkin BL, Smith DI, Tischler AS, Young WF Jr. Malignant pheochromocytoma: current status and initiatives for future progress. Endocr Relat Cancer 11, 423-436, 2004b.

Elder EE, Xu D, Hoog A, Enberg U, Hou M, Pisa P, Gruber A, Larsson C, Backdahl M. KI-67 AND hTERT expression can aid in the distinction between malignant and benign pheochromocytoma and paraganglioma. Mod Pathol 16, 246-255, 2003.

Favier J, Plouin PF, Corvol P, Gasc JM. Angiogenesis and vascular architecture in pheochromocytomas: distinctive traits in malignant tumors. Am J Pathol 161, 1235-1246, 2002. 
Favier J, Gimenez-Roqueplo AP. Pheochromocytomas: the (pseudo)-hypoxia hypothesis. Best Pract Res Clin Endocrinol Metab 24, 957-968, 2010.

Favier J, Gimenez-Roqueplo AP. [Genetics of paragangliomas and pheochromocytomas]. Med Sci (Paris) 28, 625$632,2012$.

Favier J, Amar L, Gimenez-Roqueplo AP. Paraganglioma and phaeochromocytoma: from genetics to personalized medicine. Nat Rev Endocrinol 11, 101-111, 2015.

Fishbein L, Merrill S, Fraker DL, Cohen DL, Nathanson KL. Inherited mutations in pheochromocytoma and paraganglioma: why all patients should be offered genetic testing. Ann Surg Oncol 20, 1444-1450, 2013.

Fishbein L, Khare S, Wubbenhorst B, DeSloover D, D’Andrea K, Merrill S, Cho NW, Greenberg RA, Else T, Montone K, LiVolsi V, Fraker D, Daber R, Cohen DL, Nathanson KL. Whole-exome sequencing identifies somatic ATRX mutations in pheochromocytomas and paragangliomas. Nat Commun 6, 6140, 2015.

Fishbein L. Pheochromocytoma and paraganglioma: genetics, diagnosis, and treatment. Hematol Oncol Clin North Am 30, 135-150, 2016.

Fishbein L, Leshchiner I, Walter V, Danilova L, Robertson AG, Johnson A et al. Abstract 4371: Integrated molecular characterization of pheochromocytoma and paraganglioma including a novel, recurrent and prognostic fusion gene. Cancer Research 76, 4371, 2016.

Fishbein L, Leshchiner I, Walter V, Danilova L, Robertson AG, Johnson AR et al. Comprehensive molecular characterization of pheochromocytoma and paraganglioma. Cancer Cell 31, 181-193, 2017.

Galan SR, Kann PH. Genetics and molecular pathogenesis of pheochromocytoma and paraganglioma. Clin Endocrinol (Oxf) 78, 165-175, 2013.

Geli J, Kiss N, Lanner F, Foukakis T, Natalishvili N, Larsson O, Kogner P, Hoog A, Clark GJ, Ekstrom TJ, Backdahl M, Farnebo F, Larsson C. The Ras effectors NORE1A and RASSF1A are frequently inactivated in pheochromocytoma and abdominal paraganglioma. Endocr Relat Cancer 14, 125-134, 2007.

Gimenez-Roqueplo AP. Genetics of paragangliomas and pheochromocytoma. Abstracts for the Ninth International Workshop on Multiple Endocrine Neoplasia (MEN2004) Journal of Internal Medicine 255, 703, 2004.

Gimenez-Roqueplo AP, Dahia PL, Robledo M. An update on the genetics of paraganglioma, pheochromocytoma, and associated hereditary syndromes. Horm Metab Res 44, 328-333, 2012.

Giubellino A, Sourbier C, Lee MJ, Scroggins B, Bullova P, Landau M, Ying W, Neckers L, Trepel JB, Pacak K. Targeting heat shock protein 90 for the treatment of malignant pheochromocytoma. PLoS One 8, e56083, 2013.

Guo Z, Lloyd RV. Pheochromocytomas and paragangliomas: an update on recent molecular genetic advances and criteria for malignancy. Adv Anat Pathol 22, 283-293, 2015.

Haghpanah V, Shooshtarizadeh P, Heshmat R, Larijani B, Tavangar SM. Immunohistochemical analysis of survivin expression in thyroid follicular adenoma and carcinoma. Appl Immunohistochem Mol Morphol 14, 422425, 2006.

Hasani-Ranjbar S1, Amoli MM, Ebrahim-Habibi A, Haghpanah V, Hejazi M, Soltani A, Larijani B. Mutation screening of VHL gene in a family with malignant bilateral pheochromocytoma: from isolated familial pheochromocytoma to von Hippel-Lindau disease. Fam Cancer 8, 465-471, 2009.

Hasani-Ranjbar S, Amoli MM, Ebrahim-Habibi A, Gozashti MH, Khalili N, Sayyahpour FA, Hafeziyeh J, Soltani A, Larijani B. A new frameshift MEN1 gene mutation associated with familial malignant insulinomas. Fam Cancer 10, 343-348, 2011.

Helman LJ, Cohen PS, Averbuch SD, Cooper MJ, Keiser HR, Israel MA. Neuropeptide Y expression distinguishes malignant from benign pheochromocytoma. J Clin Oncol 7, 1720-1725, 1989.

Jones PA. DNA methylation and cancer. Cancer Res 46, 461-466, 1986.

Juhlin CC, Stenman A, Haglund F, Clark VE, Brown TC, Baranoski J, Bilguvar K, Goh G, Welander J, Svahn F, Rubinstein JC, Caramuta S, Yasuno K, Gunel M, Backdahl M, Gimm O, Soderkvist P, Prasad ML, Korah R, Lifton RP, Carling T. Whole-exome sequencing defines the mutational landscape of pheochromocytoma and identifies KMT2D as a recurrently mutated gene. Genes Chromosomes Cancer 54, 542-554, 2015.

Kajbafzadeh AM, Payabvash S, Salmasi AH, Monajemzadeh M, Tavangar SM. Smooth muscle cell apoptosis and defective neural development in congenital ureteropelvic junction obstruction. J Urol 176, 718-723, 2006.

Khatami F, Noorinayer B, Ghiasi S, Mohebi R, Hashemi M, Zali MR. Lack of effects of single nucleotide polymorphisms of the DNA methyltransferase 1 gene on gastric cancer in Iranian patients: a case control study. Asian Pac J Cancer Prev 10, 1177-1182, 2009a.

Khatami F, Noorinayer B, Mohebi SR, Ghiasi S, Mohebi R, Hashemi M, Zali MR. Effects of amino acid substitution polymorphisms of two DNA methyltransferases on susceptibility to sporadic colorectal cancer. Asian Pac J Cancer Prev 10, 1183-1188, 2009 b. 
Khatami F, Tavangar SM. Current diagnostic status of pheochromocytoma and future perspective: A mini review. Iran J Pathol 12, 313-322, 2017.

Khatami F, Larijani B, Tavangar SM Circulating tumor BRAF mutation and personalized thyroid cancer treatment. Asian Pac J Cancer Prev 18, 293-294, 2017a.

Khatami F, Aghayan HR, Sanaei M, Heshmat R, Tavangar SM, Larijani B. The potential of circulating tumor cells in personalized management of breast cancer: A systematic review. Acta Med Iran 55, 175-193, $2017 \mathrm{~b}$.

Kidd M, Drozdov I, Modlin I. Blood and tissue neuroendocrine tumor gene cluster analysis correlate, define hallmarks and predict disease status. Endocr Relat Cancer 22, 561-575, 2015.

Kimura N, Takayanagi R, Takizawa N, Itagaki E, Katabami T, Kakoi N, Rakugi H, Ikeda Y, Tanabe A, Nigawara T, Ito S, Kimura I, Naruse M; Phaeochromocytoma Study Group in Japan. Pathological grading for predicting metastasis in phaeochromocytoma and paraganglioma. Endocr Relat Cancer 21, 405-414, 2014.

Kleihues P, Louis DN, Scheithauer BW, Rorke LB, Reifenberger G, Burger PC, Cavenee WK. The WHO classification of tumors of the nervous system. J Neuropathol Exp Neurol 61, 215-229, 2002.

Kouros-Mehr H, Slorach EM, Sternlicht MD, Werb Z. GATA-3 maintains the differentiation of the luminal cell fate in the mammary gland. Cell 127, 1041-1055, 2006.

Larijani B, Shirzad M, Mohagheghi MA, Haghpanah V, Mosavi-Jarrahi AR, Tavangar SM, Vassigh AR, HosseinNezhad A, Bandarian F, Baradar-Jalili R. Epidemiologic analysis of the Tehran cancer institute data system registry (TCIDSR). Asian Pac J Cancer Prev 5, 36-39, 2004.

Lee S, Nakamura E, Yang H, Wei W, Linggi MS, Sajan MP, Farese RV, Freeman RS, Carter BD, Kaelin WG Jr, Schlisio S. Neuronal apoptosis linked to EglN3 prolyl hydroxylase and familial pheochromocytoma genes: developmental culling and cancer. Cancer Cell 8, 155-167, 2005.

Letouze E, Martinelli C, Loriot C, Burnichon N, Abermil N, Ottolenghi C, Janin M, Menara M, Nguyen AT, Benit P, Buffet A, Marcaillou C, Bertherat J, Amar L, Rustin P, De Reynies A, Gimenez-Roqueplo AP, Favier J. SDH mutations establish a hypermethylator phenotype in paraganglioma. Cancer Cell 23, 739-752, 2013.

Li SC, Essaghir A, Martijn C, Lloyd RV, Demoulin JB, Oberg K, Giandomenico V. Global microRNA profiling of well-differentiated small intestinal neuroendocrine tumors. Mod Pathol 26, 685-696, 2013.

Linnoila RI, Keiser HR, Steinberg SM, Lack EE. Histopathology of benign versus malignant sympathoadrenal paragangliomas: clinicopathologic study of 120 cases including unusual histologic features. Hum Pathol 21, 1168-1180, 1990.

Lopez-Jimenez E, Gomez-Lopez G, Leandro-Garcia LJ, Munoz I, Schiavi F, Montero-Conde C, de Cubas AA, Ramires R, Landa I, Leskela S, Maliszewska A, Inglada-Perez L, de la Vega L, Rodriguez-Antona C, Leton R, Bernal C, de Campos JM, Diez-Tascon C, Fraga MF, Boullosa C, Pisano DG, Opocher G, Robledo M, Cascon A. Research resource: transcriptional profiling reveals different pseudohypoxic signatures in SDHB and VHLrelated pheochromocytomas. Mol Endocrinol 24, 2382-2391, 2010.

Majidi M, Haghpanah V, Hedayati M, Khashayar P, Mohajeri-Tehrani MR, Larijani B. A family presenting with multiple endocrine neoplasia type 2B: A case report. J Med Case Rep 5, 587, 2011.

Mannelli M, Castellano M, Schiavi F, Filetti S, Giacche M, Mori L, Pignataro V, Bernini G, Giache V, Bacca A, Biondi B, Corona G, Di Trapani G, Grossrubatscher E, Reimondo G, Arnaldi G, Giacchetti G, Veglio F, Loli P, Colao A, Ambrosio MR, Terzolo M, Letizia C, Ercolino T, Opocher G; Italian Pheochromocytoma/Paraganglioma Network. Clinically guided genetic screening in a large cohort of italian patients with pheochromocytomas and/or functional or nonfunctional paragangliomas. J Clin Endocrinol Metab 94, 1541-1547, 2009.

Margetts CD, Morris M, Astuti D, Gentle DC, Cascon A, McRonald FE, Catchpoole D, Robledo M, Neumann HP, Latif F, Maher ER. Evaluation of a functional epigenetic approach to identify promoter region methylation in phaeochromocytoma and neuroblastoma. Endocr Relat Cancer 15, 777-786, 2008.

McNeil AR, Blok BH, Koelmeyer TD, Burke MP, Hilton JM. Phaeochromocytomas discovered during coronial autopsies in Sydney, Melbourne and Auckland. Aust N Z J Med 30, 648-652, 2000.

Modlin IM, Frilling A, Salem RR, Alaimo D, Drymousis P, Wasan HS, Callahan S, Faiz O, Weng L, Teixeira N, Bodei L, Drozdov I, Kidd M. Blood measurement of neuroendocrine gene transcripts defines the effectiveness of operative resection and ablation strategies. Surgery 159, 336-347, 2016.

Mohammadi-asl J, Larijani B, Khorgami Z, Tavangar SM, Haghpanah V, Kheirollahi M, Mehdipour P. Qualitative and quantitative promoter hypermethylation patterns of the P16, TSHR, RASSF1A and RAR $\beta 2$ genes in papillary thyroid carcinoma. Med Oncol 28, 1123-1128, 2011.

Mulukutla SN, Rednam SP, Plon SE, Balazs AE. SUN-005: The role of genetics in pheochromocytoma/paraganglioma. Pediatrics-Case Reports II (posters). Endocrine Society's 98th Annual Meeting and Expo, April 1-4, 2016, Boston. 
Muscarella P, Bloomston M, Brewer AR, Mahajan A, Frankel WL, Ellison EC, Farrar WB, Weghorst CM, Li J. Expression of the p16INK4A/Cdkn2a gene is prevalently downregulated in human pheochromocytoma tumor specimens. Gene Expr 14, 207-216, 2008.

Nasseri-Moghaddam S, Malekzadeh R, Sotoudeh M, Tavangar M, Azimi K, Sohrabpour AA, Mostadjabi P, Fathi H, Minapoor M. Lower esophagus in dyspeptic Iranian patients: a prospective study. J Gastroenterol Hepatol $18,315-321,2003$.

Neumann HP, Bausch B, McWhinney SR, Bender BU, Gimm O, Franke G, Schipper J, Klisch J, Altehoefer C, Zerres K, Januszewicz A, Eng C, Smith WM, Munk R, Manz T, Glaesker S, Apel TW, Treier M, Reineke M, Walz MK, Hoang-Vu C, Brauckhoff M, Klein-Franke A, Klose P, Schmidt H, Maier-Woelfle M, Peçzkowska M, Szmigielski C, Eng C; Freiburg-Warsaw-Columbus Pheochromocytoma Study Group. Germ-line mutations in nonsyndromic pheochromocytoma. N Engl J Med 346, 1459-1466, 2002.

Nolting S, Grossman AB. Signaling pathways in pheochromocytomas and paragangliomas: prospects for future therapies. Endocr Pathol 23, 21-33, 2012.

Ohta S, Lai EW, Pang AL, Brouwers FM, Chan WY, Eisenhofer G, de Krijger R, Ksinantova L, Breza J, Blazicek P, Kvetnansky R, Wesley RA, Pacak K. Downregulation of metastasis suppressor genes in malignant pheochromocytoma. Int J Cancer 114, 139-143, 2005.

Oishi T, Iino K, Okawa Y, Kakizawa K, Matsunari S, Yamashita M, Taniguchi T, Maekawa M, Suda T, Oki Y. DNA methylation analysis in malignant pheochromocytoma and paraganglioma. J Clin Transl Endocrinol 7, 1220, 2016.

Palmada M, Kanwal S, Rutkoski NJ, Gustafson-Brown C, Johnson RS, Wisdom R, Carter BD. c-jun is essential for sympathetic neuronal death induced by NGF withdrawal but not by p75 activation. J Cell Biol 158, 453-461, 2002.

Peczkowska M, Cwikla J, Kidd M, Lewczuk A, Kolasinska-Cwikla A, Niec D, Michalowska I, Prejbisz A, Januszewicz A, Chiarelli J, Bodei L, Modlin I. The clinical utility of circulating neuroendocrine gene transcript analysis in well-differentiated paragangliomas and pheochromocytomas. Eur J Endocrinol 176, 143-157, 2017.

Pavel M, Jann H, Prasad V, Drozdov I, Modlin IM, Kidd M. NET blood transcript analysis defines the crossing of the clinical rubicon: When stable disease becomes progressive. Neuroendocrinology 104, 170-182, 2017.

Perrino CM, Ho A, Dall CP, Zynger DL. Utility of GATA3 in the differential diagnosis of pheochromocytoma. Histopathology 71, 475-479, 2017.

Pillai S, Gopalan V, Smith RA, Lam AK. Updates on the genetics and the clinical impacts on phaeochromocytoma and paraganglioma in the new era. Crit Rev Oncol Hematol 100, 190-208, 2016.

Rao D, Peitzsch M, Prejbisz A, Hanus K, Fassnacht M, Beuschlein F, Brugger C, Fliedner S, Langton K, Pamporaki C, Gudziol V, Stell A, Januszewicz A, Timmers HJLM, Lenders JWM, Eisenhofer G. Plasma methoxytyramine: clinical utility with metanephrines for diagnosis of pheochromocytoma and paraganglioma. Eur J Endocrinol 177, 103-113, 2017.

Saffar H, Sanii S, Heshmat R, Haghpanah V, Larijani B, Rajabiani A, Azimi S, Tavangar SM. Expression of galectin-3, $\mathrm{nm}-23$, and cyclooxygenase-2 could potentially discriminate between benign and malignant pheochromocytoma. Am J Clin Pathol 135, 454-460, 2011.

Salajegheh A, Smith RA, Kasem K, Gopalan V, Nassiri MR, William R, Lam AK. Single nucleotide polymorphisms and mRNA expression of VEGF-A in papillary thyroid carcinoma: potential markers for aggressive phenotypes. Eur J Surg Oncol 37, 93-99, 2011.

Salajegheh A, Pakneshan S, Rahman A, Dolan-Evans E, Zhang S, Kwong E, Gopalan V, Lo CY, Smith RA, Lam AK. Co-regulatory potential of vascular endothelial growth factor-A and vascular endothelial growth factor-C in thyroid carcinoma. Hum Pathol 44, 2204-2212, 2013.

Salmenkivi K, Haglund C, Ristimaki A, Arola J, Heikkila P. Increased expression of cyclooxygenase-2 in malignant pheochromocytomas. J Clin Endocrinol Metab 86, 5615-5619, 2001.

Salmenkivi K, Heikkila P, Liu J, Haglund C, Arola J. VEGF in 105 pheochromocytomas: enhanced expression correlates with malignant outcome. AMPIS 111, 458-464, 2003.

Salmenkivi K, Heikkila P, Haglund C, Arola J. Malignancy in pheochromocytomas. AMPIS 112, 551-559, 2004.

Sandgren J, Andersson R, Rada-Iglesias A, Enroth S, Akerstrom G, Dumanski JP, Komorowski J, Westin G, Wadelius C. Integrative epigenomic and genomic analysis of malignant pheochromocytoma. Exp Mol Med 42, 484-502, 2010.

Sanii S, Saffar H, Tabriz HM, Qorbani M, Haghpanah V, Tavangar SM. Expression of matrix metalloproteinase-2, but not caspase-3, facilitates distinction between benign and malignant thyroid follicular neoplasms. Asian Pac J Cancer Prev 13, 2175-2178, 2012. 
Sarmadi S, Izadi-Mood N, Sotoudeh K, Tavangar SM. Altered PTEN expression; a diagnostic marker for differentiating normal, hyperplastic and neoplastic endometrium. Diagn Pathol 4, 41, 2009.

Scholz T, Schulz C, Klose S, Lehnert H. Diagnostic management of benign and malignant pheochromocytoma. Exp Clin Endocrinol Diabetes 115, 155-159, 2007.

Shuch B, Ricketts CJ, Metwalli AR, Pacak K, Linehan WM. The genetic basis of pheochromocytoma and paraganglioma: implications for management. Urology 83, 1225-1232, 2014.

Stenstrom G, Svardsudd K. Pheochromocytoma in Sweden 1958-1981. An analysis of the National Cancer Registry Data. Acta Med Scand 220, 225-232, 1986.

Strong VE, Kennedy T, Al-Ahmadie H, Tang L, Coleman J, Fong Y, Brennan M, Ghossein RA. Prognostic indicators of malignancy in adrenal pheochromocytomas: clinical, histopathologic, and cell cycle/apoptosis gene expression analysis. Surgery 143, 759-768, 2008.

Tabriz HM, Adabi Kh, Lashkari A, Heshmat R, Haghpanah V, Larijani B, Tavangar SM. Immunohistochemical analysis of nm 23 protein expression in thyroid papillary carcinoma and follicular neoplasm. Pathol Res Pract 205, 83-87, 2009.

Tavangar SM, Larijani B, Mahta A, Hosseini SM, Mehrazine M, Bandarian F. Craniopharyngioma: a clinicopathological study of 141 cases. Endocr Pathol 15, 339-344, 2004.

Tavangar SM, Shariftabrizi A, Soroush AR. Her-2/neu over-expression correlates with more advanced disease in Iranian colorectal cancer patients. Med Sci Monit 11, CR123-CR126, 2005.

Tavangar SM, Monajemzadeh M, Larijani B, Haghpanah V. Immunohistochemical study of oestrogen receptors in 351 human thyroid glands. Singapore Med J 48, 744-747, 2007.

Tavangar SM, Shojaee A, Moradi Tabriz H, Haghpanah V, Larijani B, Heshmat R, Lashkari A, Azimi S. Immunohistochemical expression of Ki67, c-erbB-2, and c-kit antigens in benign and malignant pheochromocytoma. Pathol Res Pract 206, 305-309, 2010.

Thompson LD. Pheochromocytoma of the Adrenal gland Scaled Score (PASS) to separate benign from malignant neoplasms: a clinicopathologic and immunophenotypic study of 100 cases. Am J Surg Pathol 26, 551-566, 2002.

Thouennon E, Elkahloun AG, Guillemot J, Gimenez-Roqueplo AP, Bertherat J, Pierre A, Ghzili H, Grumolato L, Muresan M, Klein M, Lefebvre H, Ouafik L, Vaudry H, Plouin PF, Yon L, Anouar Y. Identification of potential gene markers and insights into the pathophysiology of pheochromocytoma malignancy. J Clin Endocrinol Metab 92, 4865-4872, 2007.

van der Harst E, Bruining HA, Jaap Bonjer H, van der Ham F, Dinjens WN, Lamberts SW, de Herder WW, Koper JW, Stijnen T, Proye C, Lecomte-Houcke M, Bosman FT, de Krijger RR. Proliferative index in phaeochromocytomas: does it predict the occurrence of metastases? J Pathol 191, 175-180, 2000.

Vaque JP, Fernandez-Garcia B, Garcia-Sanz P, Ferrandiz N, Bretones G, Calvo F, Crespo P, Marin MC, Leon J. cMyc inhibits Ras-mediated differentiation of pheochromocytoma cells by blocking c-Jun up-regulation. Mol Cancer Res 6, 325-339, 2008.

Vogel KS, Brannan CI, Jenkins NA, Copeland NG, Parada LF. Loss of neurofibromin results in neurotrophin-independent survival of embryonic sensory and sympathetic neurons. Cell 82, 733-742, 1995.

Welander J, Andreasson A, Brauckhoff M, Backdahl M, Larsson C, Gimm O, Soderkvist P. Frequent EPAS1/HIF2a exons 9 and 12 mutations in non-familial pheochromocytoma. Endocr Relat Cancer 21, 495-504, 2014.

Walenkamp A, Crespo G, Fierro Maya F, Fossmark R, Igaz P, Rinke A, Tamagno G, Vitale G, Oberg K, Meyer T. Hallmarks of gastrointestinal neuroendocrine tumours: implications for treatment. Endocr Relat Cancer 21, R445-R460, 2014.

Wilzen A, Rehammar A, Muth A, Nilsson O, Tesan Tomic T, Wangberg B, Kristiansson E, Abel F. Malignant pheochromocytomas/paragangliomas harbor mutations in transport and cell adhesion genes. Int J Cancer 138, 2201-2211, 2016.

Yalcin S, Oberg K (Eds). Neuroendocrine Tumours. Diagnosis and Management. Springer-Verlag Berlin Heidelberg, 2015.

Yang C, Zhuang Z, Fliedner SM, Shankavaram U, Sun MG, Bullova P, Zhu R, Elkahloun AG, Kourlas PJ, Merino M, Kebebew E, Pacak K. Germ-line PHD1 and PHD2 mutations detected in patients with pheochromocytoma/paraganglioma-polycythemia. J Mol Med (Berl) 93, 93-104, 2015.

Yon L, Guillemot J, Montero-Hadjadje M, Grumolato L, Leprince J, Lefebvre H, Contesse V, Plouin PF, Vaudry H, Anouar Y. Identification of the secretogranin II-derived peptide EM66 in pheochromocytomas as a potential marker for discriminating benign versus malignant tumors. J Clin Endocrinol Metab 88, 2579-2585, 2003.

Yu R, Nissen NN, Chopra P, Dhall D, Phillips E, Wei M. Diagnosis and treatment of pheochromocytoma in an academic hospital from 1997 to 2007. Am J Med 122, 85-95, 2009. 
Yuan W, Wang W, Cui B, Su T, Ge Y, Jiang L, Zhou W, Ning G. Overexpression of ERBB-2 was more frequently detected in malignant than benign pheochromocytomas by multiplex ligation-dependent probe amplification and immunohistochemistry. Endocr Relat Cancer 15, 343-350, 2008.

Zhikrivetskaya SO, Snezhkina AV, Zaretsky AR, Alekseev BY, Pokrovsky AV, Golovyuk AL, Melnikova NV, Stepanov OA, Kalinin DV, Moskalev AA, Krasnov GS, Dmitriev AA, Kudryavtseva AV. Molecular markers of paragangliomas/pheochromocytomas. Oncotarget 8, 25756-25782, 2017. 